Egyptian Journal of Aquatic Biology \& Fisheries

Zoology Department, Faculty of Science,

Ain Shams University, Cairo, Egypt.

ISSN $1110-6131$

Vol. 23(2): 347-361 (2019)

www.ejabf.journals.ekb.eg

\title{
Comparison Between Effects of Sinking and Floating Diets on Growth Performance of the Nile Tilapia (Oreochromis niloticus)
}

\author{
Abdelhamid M. Abdelhamid ${ }^{1 *}$, Mahmoud F. Salem ${ }^{2}$ and Mohammed El-Sh. Ramadan ${ }^{1}$ \\ 1- Department of Animal Production, Faculty of Agriculture, Mansoura University, \\ Mansoura, Egypt. \\ 2- Aquaculture Research Unit, Sakha, Central Lab. of Aquaculture Research, Agricultural \\ Research Center, Ministry of Agriculture, Cairo, Egypt \\ *Corresponding author: abdmohabd@ hotmail.com
}

ARTICLE INFO

Article History:

Received:May 4, 2019

Accepted:May 12, 2019

Online:May 16, 2019

Keywords:

Nile tilapia

Floating diets

Probiotic

Growth parameters

Feed utilization

chemical composition

\section{ABSTRACT}

The present study was conducted over 96 days in order to compare between the effects of floating and sinking diets with different levels of a probiotic on growth performance, food utilization and chemical composition with all-male mono-sex juvenile Nile tilapia (Oreochromis niloticus). The treatments were two floating and sinking diets supplemented with three levels of the probiotic PRO-LYNE ${ }^{\circledR}$, being $0 \%$, $1 \%$ and $2 \%$ of the diets. Each hapa (measuring $2 \times 3 \times 1 \mathrm{~m}^{3}$ ) was suspended in an earthen pond $\left(4000 \mathrm{~m}^{2}\right)$. There were 6 treatments, each consisting of 2 replicates, stocked with fish of average initial body weigh $60 \mathrm{~g}$. A total of 366 fish were randomly distributed into 6 experimental groups. The stocking density was 5 fish $/ \mathrm{m}^{3}$ for all the hapas. Fingerlings were fed a commercial diet containing $25.2 \%$ crude protein and at feeding rates of $4 \%$ of their fresh biomass in each hapa for the first 1.5 month and $3 \%$ until the end of the experiment. The results of the present study revealed that performance and production and economic efficiency of Nile tilapia reared in net hapas in earthen ponds significantly increased, when they were fed the floating pellets supplemented with probiotic at level $1 \%$.

\section{INTRODUCTION}

Aquaculture is the fastest growing sector of food animal production in the world and supplies an increasing percentage of the total production of fish for human consumption (FAO, 2012). Nowadays, Egyptian fish production from aquaculture contributed by $80 \%$ of total fish production which amounted 1.8 million metric tons (Abdelhamid, 2019a). Tilapia in different countries is farmed with fertilization and/or supplementary feeding. Feed is the highest cost-oriented input in aquaculture. Thus, the higher the effective feed the less will be the cost of production. Mono-sex Oreochromis niloticus does not breed/multiply, which makes it easy for fish farmers to avoid uncontrolled breeding in their farms. They grow fast and attain market size within a short period than other tilapia forms. This fish is currently considered to be the most important and commonly cultured species around the world and constitutes over $70 \%$ of cultured tilapia (Fitzsimmons, 2004), which represent approximately $6 \%$ of total farmed fish production (FAO, 2004). Feed is one of the operating costs mostly limiting the expansion of cultured species (Sorensen, 2012). 
Feeds commonly accounts for $40-60 \%$ of the operating costs depending on the level of intensification and species (Kannadhason et al., 2009 and Limbu and Jumanne, 2014). In 2008, global production of Nile tilapia was 2.1 million tons more than double that recorded in 2000 (FAO, 2012). In addition, tilapia producers have been intensifying their farming practices, thus contributing to higher farm yields (Lim et al., 2006). In recent years, probiotics and prebiotics are under extensive investigation for their potential beneficial effects on fish health, growth and survival (Verschuere et al., 2000; Irianto and Austin, 2002; Mussatto and Mancilha, 2007; Grisdale-Helland et al., 2008 and Yousefian and Amiri, 2009). Consequently, a number of natural and biological products, such as live bacterial suspension and dry concentrates, enzyme preparations, and extracts of plant products are being promoted for use as water and soil quality conditioners in aquaculture ponds (Defoirdt et al., 2011 and Cruz et al., 2012) and additives to fish feed (ElRhman et al., 2009 and Honsheng, 2010). Although an increasing volume of scientific research from aquatic animals suggests that the establishment, maintenance and enhancement of health promoting bacteria in the intestine can have wide ranging beneficial effects on growth and survival of the host (Verschuere et al., 2000; Irianto and Austin, 2002; Mussatto and Mancilha, 2007; Zhou et al., 2007; Burr et al., 2008; Grisdale-Helland et al., 2008; Yousefian and Amiri, 2009 and El-Rhman et al., 2009), results have been conflicting (Merrifield et al., 2010). While some researchers have shown that inclusion of probiotic and/or probiotics in the diet of fish or direct inoculation into the aquatic environment changes gut microbiota, improves growth and survival, or improves water quality (Aly et al., 2008; Wang et al., 2008 and Merrifield et al., 2010). Others have reported no beneficial effects (Shelby et al., 2006; Marzouk et al., 2008; El-Rhman et al., 2009 and Ferguson et al., 2010). Hence, the aim of the present study was to compare the effect of commercially produced sinking and floating pellets supplemented with probiotic (PRO-LYNE ${ }^{\circledR}$ ) on growth performance, food utilization, body composition and economic efficiency of juveniles Nile tilapia, $O$. niloticus.

\section{MATERIALS AND METHODS}

The present work was conducted in a private fish farm (for the owner Hag Aboulenin) in Metubus - Kafr El-Sheikh governorate during season 2017 in order to compare between effects of floating and sinking diets supplemented with graded levels of the commercial probiotic (PRO-LYNE ${ }^{\circledR}$ ), being zero, 1 and $2 \%$ of the diet on growth performance, food utilization and chemical composition of Nile tilapia $(O$. niloticus), reared in net hapas under Egyptian conditions.

Experimental fish: A total number of 360 Nile tilapia with an average bodyweight of $60 \mathrm{~g}$ were obtained from a private fish farm at Metubus area, belonging to Kafr ElSheikh governorate, Egypt. The experimental period was 96 days (from 23/6 to 26/9/ 2017).

Experimental design of rearing fish: Each size of fishes was randomly distributed among 12 hapas. Each hapa measuring $\left(2 \times 3 \times 1 \mathrm{~m}^{3}\right)$ as width, length, and depth, respectively. Hapas were suspended in an earthen pond of $4000 \mathrm{~m}^{2}$. The stocking densities were $5 \mathrm{fish} / \mathrm{m}^{3}$ at a constant rate in all the hapas. Five fishes were kept frozen at $-20{ }^{\circ} \mathrm{C}$ for chemical analysis at the beginning of the experiment. The pond was supplied with fresh water from Metubus area. The water exchange rate was $15 \%$ of total ponds water volume/day. 
Experimental diets and feeding regime: Nile tilapia fingerlings were fed a commercial diet containing $25.2 \%$ crude protein and $4625 \mathrm{Kcal} / \mathrm{Kg}$ gross energy at feeding rates of $4 \%$ of their fresh biomass in each hapa for the first 1.5 month and $3 \%$ until the end of the experiment (six days per week). Fish were fed two times daily at 8 a.m. and 2 p.m. with feed amounts adjusted at approximately 14 dayintervals in response to their actual body weight. Ingredients and composition of the experimental diets are presented in Table 1. A sinking diet and floating one was formulated with the aid of a computer program (Winfeed 2.8) using locally available ingredients. The ingredients used were fish meal (Rastrineobola Argentina), whole maize, whole soybean, rice bran, wheat bran, vitamins-minerals premix and commercial probiotic PRO-LYNE ${ }^{\circledR}$.

Experimental dietary additives: Product name: PRO-LYNE ${ }^{\circledR}$. It consisting of condensed molasses fermentation solubles (MOS), Bacillus subtilus, enzymes (xylanase, hemicellulase, $\beta$-glucanase) and sodium bentonite. Arsenic (As) $<0.0001$ $\%$, Heavy metals $(\mathrm{Pb})<0.0005$, Product use in animal feeds as a probiotic. Company name: ProByn International Inc. Address: 123 W. St. Charles Road, Unit 200, Lombard, IL 60148, USA.

Table 1: Formulation of the control and experimental diets (\%)

\begin{tabular}{|c|c|c|c|c|c|c|}
\hline \multirow[t]{2}{*}{ Ingredients } & \multicolumn{3}{|c|}{ Floating $25.2 \%$ crude protein } & \multicolumn{3}{|c|}{ Sinking $25.2 \%$ crude protein } \\
\hline & T1 & $\mathbf{T 2}$ & T3 & T4 & T5 & T6 \\
\hline Fish meal $(65 \%, \mathrm{CP})$ & 20 & 20 & 20 & 20 & 20 & 20 \\
\hline Soybean meal & 124 & 124 & 124 & 91 & 91 & 91 \\
\hline Yellow corn & 130 & 130 & 130 & 153 & 153 & 153 \\
\hline Wheat bran & 412 & 412 & 412 & 416 & 416 & 416 \\
\hline Wheat bran red & 349 & 349 & 349 & 170 & 170 & 170 \\
\hline Rice bran & 150 & 150 & 150 & 150 & 150 & 150 \\
\hline Poultry by-products meal & 145 & 145 & 145 & 151 & 151 & 151 \\
\hline Limestone & 6 & 6 & 6 & 6 & 6 & 6 \\
\hline $\begin{array}{l}\text { Vitamins } \\
\text { premix }\end{array}$ & 3 & 3 & 3 & 3 & 3 & 3 \\
\hline Lysine & 1.5 & 1.5 & 1.5 & 1.5 & 1.5 & 1.5 \\
\hline Methionine & 1.5 & 1.5 & 1.5 & 1.5 & 1.5 & 1.5 \\
\hline Di-calcium phosphate & 4 & 4 & 4 & 4 & 4 & 4 \\
\hline Common salt & 2 & 2 & 2 & 2 & 2 & 2 \\
\hline Vitamin C & 0.5 & 0.5 & 0.5 & 0.5 & 0.5 & 0.5 \\
\hline Garlic meal & 0.3 & 0.3 & 0.3 & 0.3 & 0.3 & 0.3 \\
\hline Total & 100 & 100 & 100 & 100 & 100 & 100 \\
\hline PORO-LYNE ${ }^{\circledR}$ & Zero $\%$ & $1 \%$ & $2 \%$ & Zero $\%$ & $1 \%$ & $2 \%$ \\
\hline
\end{tabular}

The formulation and proximate composition of the diets used in the present study are given in Table 2. Ingredients for the production of sinking diet were purchased from local suppliers at the site based on nutrient composition. During the production of the sinking diet, whole maize and soybeans were processed in order to reduce anti-nutritional factors and improve nutrient bioavailability to the fish (Sinha et al., 2011). Apart from grinding, the other ingredients used in the production of the sinking diet were not subjected to any processing. Thus, whole maize and soybeans were soaked in freshwater for overnight and 8 hours, respectively. They were then boiled for 1.5 hour followed by solar-drying for about a day. Solar-drying was followed by dry cooking (roasting) and finally solar-dried again. Dried ingredients were milled into fine particles using a grinder machine (hammer mill) with a screen size of $0.8 \mathrm{~mm}$, weighed and mixed in the required proportions according to 
formulation. The mixture was then blended with sufficient hot water to form dough. Pellets were produced by extruding this dough through a meat grinder/mincer with a diameter of $4 \mathrm{~mm}$ and subsequent solar-dried for several hours until dry.

Table 2: Chemical analysis (\%) of the commercial diet and its ingredients

\begin{tabular}{lcccccccc}
\hline Ingredients & MO & DM & CP & EE & CF & $\begin{array}{c}\text { Ash } \\
\text { Nitrogen-free } \\
\text { extract } \\
\text { (NFE)* }\end{array}$ & $\begin{array}{c}\text { GE } \\
\text { (kcal/kg)** }\end{array}$ \\
\hline Fish meal & 7 & 93 & 65 & 10 & 0 & 15 & 10 & 5579 \\
Soybean meal & 12 & 88 & 48 & 4.5 & 2.2 & 5 & 40.3 & 5197.1 \\
Yellow corn & 12 & 88 & 7.7 & 3.8 & 2.3 & 1.4 & 84.8 & 4336.0 \\
Wheat bran & 11 & 89 & 13 & 4 & 8 & 6 & 69 & 4051.6 \\
Wheat bran red & 13 & 87 & 16 & 4.2 & 16 & 7 & 56.8 & 2739.2 \\
Rice bran & 11.3 & 88.7 & 13.5 & 15 & 9.9 & 9.6 & 52 & 4425.5 \\
Gluten & 9.6 & 90.4 & 62 & 3 & 2.1 & 5 & 27.9 & 5457.1 \\
Poultry by-product & 12 & 88 & 58 & 12 & 2 & 16 & 12 & 5395 \\
meal & & & & & & & & \\
Commercial diet & 11 & 89 & 25.2 & 7.5 & 5.4 & 6.3 & 55.6 & 4625.6 \\
\hline
\end{tabular}

$*$ : Nitrogen free extract (NFE) $=100-(\mathrm{CP} \%+\mathrm{EE} \%+\mathrm{CF} \%+$ ash \%). **: GE= Gross energy was calculated by multiply the factors $4.1,6.5$ and $9.44 \mathrm{Kilo}$ GE/g DM for carbohydrate, protein and fat, respectively (Jobling, 1983).

Water quality analysis: Water samples were taken monthly for determination of $\mathrm{pH}$, dissolved oxygen (DO), contents of nitrite, nitrate and unionized ammonia. Average values of water quality parameters are illustrated in Table 4. Analytical methods were done according to the American Public Health Association (APHA, 2005). The $\mathrm{pH}$ values were determined by digital $\mathrm{pH}$ meter (Orient Research Model 201). The water temperature; Seccki disk reading (transparency) and oxygen saturation were measured daily at 8:00 a.m. by an oxygen-meter (model 9070, Scientific Instrument).

Proximate analysis of the experimental diets and fish body: Chemical composition of the control and experimental diets was done at the start and for fish body at the start and at the end of the experiment according to the methods described by A.O.A.C (1990). At the end of the experimental, five fish were derived from each group for drying at $60^{\circ} \mathrm{C}$ for 48 hours and then milled through electrical mill and stored frozen until analysis.

Growth performance and efficiency of feed and protein utilization: Average total gain (ATG, g/fish), average daily gain (ADG, g/fish/ day), specific growth rate (SGR, \%/d), feed conversion ratio (FCR), feed efficiency, protein efficiency ratio (PER), protein productive value (PPV, \%), condition factor $(\mathrm{k})$ and survival rate (SR, $\%)$ were calculated according to the following equations:

ATG $(\mathrm{g} / \mathrm{fish})=[$ Average finale weigh $(\mathrm{g})$-Average initial weigh $(\mathrm{g})]$.

ADG (g/fish/ day) $=$ ATG $(\mathrm{g}) /$ experimental period $(\mathrm{d})$.

SGR $(\% /$ day $)=(\ln$ final body weight $-\ln$ initial body weight $) \times 100 /$

experimental period $(\mathrm{d})$.

FCR = feed intake (g) / live weight gain $(\mathrm{g})$.

Feed efficiency $=$ live weight gain $(\mathrm{g}) /$ feed intake $(\mathrm{g})$

PER $=$ Live weight gain $(\mathrm{g}) /$ protein intake $(\mathrm{g})$.

PPV $(\%)=100$ [final fish body protein $(\mathrm{g})$ - initial fish body protein $(\mathrm{g})$ ] / crude protein intake $(\mathrm{g})$.

Condition factor $(\mathrm{K})=$ live body weight $(\mathrm{g}) /(\text { body length, } \mathrm{cm})^{3}$ x 100 
SR $(\%)=100$ [total No. of fish at the end of the experimental period / total No. of fish at the start of the experiment].

Statistical analysis: Numerical data was statistically analyzed as factorial design (2 food types x 3 probiotic levels) using SAS (2006) and Duncan (1955).

\section{RESULTS AND DISCUSSION}

Chemical composition of the experimental diet: Chemical composition of the different experimental diets is shown in Table 3. The crude protein (CP) content of the sinking pellets was between 25.2 and $26.0 \%$, and that of the floating ones lay within $25.2-25.9 \%$. The crude fat and gross energy contents of the floating pellets (7.5 - 8.2\% and 4626- $4676 \mathrm{kcal} / \mathrm{kg}$ feed, respectively), were higher than in the sinking pellets (being 7.5- 8.1\% and $4626-4669 \mathrm{kcal} / \mathrm{kg}$ feed, respectively). The ash in sinking pellets was 6.3- $6.7 \%$ and in floating pellets was $6.3-6.6 \%$. Chemical analysis of the two types of pellets indicated that the crude protein contents were higher than the guaranteed analysis provided by the manufacturer, while such level was within the range suggested by NRC (1993) for the practical diets for tilapia. However, it was nearly similar to that used by Abdel-Maksoud et al. (1998). In this respect, Santiago and Lovell (1988) recommended the optimum protein requirement for growth of Nile tilapia as $25-35 \%$, where the dietary protein content level in the present study, agrees with their recommendation.

Table 3: Chemical analysis (\% DM basis) of the experimental diets

\begin{tabular}{ccccccc}
\hline Ingredients & Floating diet $\mathbf{2 5 . 2}$ \% $\mathbf{C P}$ & \multicolumn{3}{c}{ Sinking diet $\mathbf{2 5 . 2} \% \mathbf{C P}$} \\
& $\mathbf{T 1}$ & $\mathbf{T 2}$ & $\mathbf{T 3}$ & $\mathbf{T 4}$ & $\mathbf{T 5}$ & $\mathbf{T 6}$ \\
Dry matter (DM) & 89 & 89 & 90 & 89 & 90 & 91 \\
Crude protein (CP) & 25.2 & 25.7 & 25.9 & 25.2 & 25.8 & 26.00 \\
Ether extract (EE) & 7.5 & 7.9 & 8.2 & 7.5 & 7.8 & 8.1 \\
Crude fiber (CF) & 5.4 & 5.3 & 5.2 & 5.4 & 5.4 & 5.2 \\
Ash & 6.3 & 6.4 & 6.6 & 6.3 & 6.5 & 6.7 \\
Nitrogen-free extract (NFE)* & 55.6 & 54.7 & 54.1 & 55.6 & 54.5 & 54 \\
GE (kcal/kg)** & 4626 & 4659 & 4676 & 4626 & 4648 & 4669 \\
DE (kcal/kg) & 304.7 & 309 & 311.5 & 304.7 & 308.2 & 310.9 \\
P/E (mg CP/kcal GE) & 5.44 & 5.51 & 5.54 & 5.45 & 5.55 & 5.57 \\
\hline
\end{tabular}

DM: dry matter, CP: crude protein, EE: ether extract, CF: crude fibers, DE: digestible energy, P/E: protein: energy ratio. * Nitrogen free extract $(\mathrm{NFE})=100-(\mathrm{CP} \%+\mathrm{EE} \%+\mathrm{CF} \%+$ ash $\%)$. ** GE $=\mathrm{Gross}$ energy was calculated by multiply the Factors 4.1, 6.5 and 9.44 Kilo GE/g DM for carbohydrate, protein and fat, respectively (Jobling, 1983). DE (digestible energy) $(\mathrm{kcal} / \mathrm{g}$ ), based on $5.0 \mathrm{kcal} / \mathrm{g}$ protein $9.0 \mathrm{kcal} / \mathrm{g}$ EE, $2.0 \mathrm{kcal} / \mathrm{g}$ NFE, according to Wee and Shu (1989).

Quality parameters of rearing water: Water temperatures and $\mathrm{pH}$ remained fairly stable among all treatments (Table 4). Water temperature $\left(24.9-26.2{ }^{\circ} \mathrm{C}\right), \mathrm{pH}$ $\left(6.8\right.$ - 6.7), nitrite $(0.20-0.26 \mathrm{mg} / \mathrm{L})$, total alkalinity $\left(>300 \mathrm{mg} / \mathrm{L} \mathrm{CaCO}_{3}\right)$ and total hardness (> $300 \mathrm{mg} / \mathrm{L} \mathrm{CaCO}_{3}$ ) were within the optimum range recommended for culture of Nile tilapia (Nwanna, 2002). DO ranged from $3.8 \pm 0.22 \mathrm{mg} / \mathrm{L}$ to $4.1 \pm$ $0.22 \mathrm{mg} / \mathrm{L}$. Unionized ammonia concentration ranged from $0.09 \pm 0.017 \mathrm{mg} / \mathrm{L}$ to $0.11 \pm 0.017 \mathrm{mg} / \mathrm{L}$ (Table 4). All the measured water quality parameters did not differ significantly $(\mathrm{P}>0.05)$ among the feeding treatments throughout the study. All tested water quality criteria (Table 4) were suitable for rearing Nile tilapia fingerlings as cited by Abdel-Hakim et al. (2002). Also, Abdelhamid et al. (2002) suggested that these values are acceptable for rearing Nile tilapia. These results pinpoint that, 
farming Nile tilapia using floating and sinking diets does not cause significant deterioration of water quality parameters providing that the diets were formulated correctly. The unionized ammonia and nitrite levels in the present study remained within safe limits; hence, no remarkable mortality (Table 6) was recorded and no signs of stress were observed. Maximum values of $0.11 \mathrm{mg} / \mathrm{L}$ for ammonia and 0.26 $\mathrm{mg} / \mathrm{L}$ for nitrite were far below the toxic levels. Safe levels of unionized ammonia were indicated as $1.05 \mathrm{mg} / \mathrm{L}$ (Hassan, 1992) and $1.0 \mathrm{mg} / \mathrm{L}$ for nitrite (Otte and Rosenthal, 1979). Data of the water quality parameters monitored during the study period was within the satisfactory range for tilapia culture given by Boyd (1982), Rahman (1992), Abdelhamid (2019a) and Abdelhamid (1996 \& 2019b). The level of DO retention is directly influenced by water temperature. The ability of fresh water to retain an acceptable level of DO hindered water temperature exceeding $24{ }^{\circ} \mathrm{C}$. The minimum amount of DO that will support a large, diverse fish population is $4-5 \mathrm{mg} / \mathrm{L}$ as suggested by numerous scientific studies. Generally, it averages about 9.0 4-5 $\mathrm{mg} / \mathrm{L}$ for good fishing waters. The fish may die when DO concentration is lower than $3 \mathrm{mg} / \mathrm{L}$. Fish stop eating and become lethargic due to ammonia toxicity. Ammonia is released in the pond when fishes are overfed; uneaten feeds sink to the bottom of the pond and increase the load on the nitrifying bacteria in the pond and filter. Too many fish in the pond or system can also be responsible for ammonia toxicity by producing wastes (Abdel-Hakim et al., 2002).

Table 4: Rearing water quality parameters of Nile tilapia fed the floating and sinking diets supplemented with different levels of probiotic

\begin{tabular}{lccccccc}
\hline $\begin{array}{l}\text { Diets } \\
\text { Type }\end{array}$ & $\begin{array}{c}\text { P-L- } \\
\mathbf{L}^{*} \mathbf{\%}\end{array}$ & $\begin{array}{c}\text { Temperature } \\
\left({ }^{\mathbf{0}} \mathbf{C}\right)\end{array}$ & $\begin{array}{c}\text { Dissolved } \\
\text { Oxygen } \\
(\mathrm{mg} / \mathrm{L})\end{array}$ & $\mathbf{p H}$ & $\begin{array}{c}\text { Unionized } \\
\text { Ammonia } \\
(\mathrm{mg} / \mathrm{L})\end{array}$ & $\begin{array}{c}\text { Nitrate } \\
(\mathrm{mg} / \mathrm{L})\end{array}$ & $\begin{array}{c}\text { Nitrite } \\
(\mathrm{mg} / \mathrm{L})\end{array}$ \\
Floating & $\mathbf{0}$ & $24.9 \pm$ & $3.8 \pm$ & $6.9 \pm$ & $0.11 \pm$ & $0.242 \pm$ & $0.20 \pm$ \\
& $\mathbf{1}$ & $25.5 \pm$ & $4.1 \pm$ & $6.8 \pm$ & $0.09 \pm$ & $0.234 \pm$ & $0.26 \pm$ \\
& & 0.0 & 0.22 & 0.103 & 0.017 & 0.82 & 0.038 \\
& $\mathbf{2}$ & $25.1 \pm$ & $4.0 \pm$ & $6.9 \pm$ & $0.10 \pm$ & $0.240 \pm$ & $0.23 \pm$ \\
Sinking & $\mathbf{0}$ & $25.5 \pm 0$ & $4.0 \pm$ & $6.9 \pm$ & $0.09 \pm$ & $0.250 \pm$ & $0.26 \pm$ \\
& & .02 & 0.22 & 0.103 & 0.017 & 0.82 & 0.038 \\
& $\mathbf{1}$ & $26.2 \pm$ & $3.9 \pm$ & $6.8 \pm$ & $0.09 \pm$ & $0.250 \pm$ & $0.20 \pm$ \\
& & 0.1 & 0.15 & 0.07 & 0.012 & 0.58 & 0.027 \\
& $\mathbf{2}$ & $25.5 \pm$ & $3.8 \pm$ & $6.9 \pm$ & $0.10 \pm$ & $0.260 \pm$ & $0.26 \pm$ \\
& & 0.6 & 0.22 & 0.103 & 0.017 & 0.82 & 0.038 \\
\hline
\end{tabular}

*: P-L-L: PRO-LYNE ${ }^{\circledR}$ level. Mean without a similar small superscript within a column and a group differ significantly $(\mathrm{P}<0.05)$. Overall mean without a similar capital superscript within a column differ significantly $(\mathrm{P}<0.05)$.

Body weight and length: Table 5 shows mean of fish body weight and length, at the start and the end of the experiment as affected by feed type (floating and sinking pellets). As described in this table, the averages of initial weights of $O$. niloticus were $60 \mathrm{~g}$. While at the end of the experiment, the averages of body weight ranged from $198 \pm 1.18$ to $163 \pm 6.41 \mathrm{~g}$, regardless of probiotic levels. As described in this table, the averages of initial length were $14.3 \pm 0.15$ to $14.0 \pm 0.15 \mathrm{~cm}$; while at the end of the experiment, the averages of body length were $21.3 \pm 0.33$ to $19.2 \pm 0.17 \mathrm{~cm}$ for the two types, respectively. These results indicated that, the body weight and length for floating feed group were higher than those obtained for sinking feed supplemented with probiotic $(0 \%, 1 \%$, and $2 \%)$. Differences between two feeds were significant $(\mathrm{P}<0.05)$. 
Table 5: Mean \pm standard errors of body weight and length of the Nile tilapia fed floating and sinking diets supplemented with different levels of probiotic

\begin{tabular}{|c|c|c|c|c|c|c|c|}
\hline $\begin{array}{l}\text { Diets } \\
\text { type }\end{array}$ & P-L-L* \% & $\begin{array}{l}\text { Initial } \\
\text { stocking } \\
\text { density }\end{array}$ & $\begin{array}{l}\text { Final stocking } \\
\text { density }\end{array}$ & $\begin{array}{l}\text { Initial biomass } \\
\text { Kg/hapa }\end{array}$ & $\begin{array}{l}\text { Final biomass } \\
\text { Kg/hapa }\end{array}$ & $\begin{array}{l}\text { Initial length } \\
(\mathrm{cm})\end{array}$ & $\begin{array}{l}\text { Final length } \\
\text { (cm) }\end{array}$ \\
\hline \multirow[t]{3}{*}{ Floating } & $\overline{\mathbf{0}}$ & 5 & $\begin{array}{r}4.40 \pm \\
0.35^{\mathrm{a}}\end{array}$ & $\begin{array}{l}1801 \pm \\
1.00^{\mathrm{a}}\end{array}$ & $\begin{array}{l}4685 \pm \\
346^{\mathrm{b}}\end{array}$ & $\begin{array}{c}14.1 \pm \\
0.10^{\mathrm{a}}\end{array}$ & $\begin{array}{l}19.3 \pm \\
0.33^{\mathrm{c}}\end{array}$ \\
\hline & 1 & 5 & $\begin{array}{r}4.80 \pm \\
0.00^{\mathrm{a}}\end{array}$ & $\begin{array}{l}1800 \pm \\
0.00^{\mathrm{a}}\end{array}$ & $\begin{array}{l}5742 \pm 3 \\
4.7^{\mathrm{a}}\end{array}$ & $\begin{array}{l}14.3 \pm \\
0.17^{\mathrm{a}}\end{array}$ & $\begin{array}{l}21.3 \pm \\
0.33^{\mathrm{a}}\end{array}$ \\
\hline & 2 & 5 & $\begin{array}{r}4.80 \pm \\
0.00^{\mathrm{a}}\end{array}$ & $\begin{array}{l}1803 \pm \\
1.73^{\mathrm{a}}\end{array}$ & $\begin{array}{l}5463 \pm \\
34.4^{\mathrm{a}}\end{array}$ & $\begin{array}{l}14.2 \pm \\
0.09^{\mathrm{a}}\end{array}$ & $\begin{array}{l}20.3 \pm \\
0.17^{\mathrm{b}}\end{array}$ \\
\hline Overall & & 5 & $\begin{array}{l}4.67 \pm \\
0.12^{\mathrm{A}}\end{array}$ & $\begin{array}{c}1801 \pm \\
0.73^{\mathrm{A}}\end{array}$ & $\begin{array}{l}5297 \pm \\
187^{\mathrm{A}}\end{array}$ & $\begin{array}{l}14.2 \pm \\
0.07^{\mathrm{A}}\end{array}$ & $\begin{array}{l}20.3 \pm \\
0.32^{\mathrm{A}}\end{array}$ \\
\hline \multirow[t]{3}{*}{ Sinking } & 0 & 5 & $\begin{array}{l}4.43 \pm \\
0.15^{\mathrm{a}}\end{array}$ & $\begin{array}{l}1800 \pm \\
0.00^{\mathrm{a}}\end{array}$ & $\begin{array}{l}4296 \pm \\
60.3^{\mathrm{b}}\end{array}$ & $\begin{array}{l}14.3 \pm \\
0.15^{\mathrm{a}}\end{array}$ & $\begin{array}{l}19.2 \pm \\
0.17^{\mathrm{b}}\end{array}$ \\
\hline & 1 & 5 & $\begin{array}{l}4.67 \pm \\
0.09^{\mathrm{a}}\end{array}$ & $\begin{array}{l}1803 \pm \\
1.73^{\mathrm{a}}\end{array}$ & $\begin{array}{l}5137 \pm \\
108^{\mathrm{a}}\end{array}$ & $\begin{array}{l}14.1 \pm \\
0.10^{\mathrm{a}}\end{array}$ & $\begin{array}{l}20.2 \pm \\
0.44^{\mathrm{a}}\end{array}$ \\
\hline & 2 & 5 & $\begin{array}{l}4.50 \pm \\
0.00^{\mathrm{a}}\end{array}$ & $\begin{array}{l}1800 \pm \\
0.00^{\mathrm{a}}\end{array}$ & $\begin{array}{l}4995 \pm \\
0.00^{\mathrm{a}}\end{array}$ & $\begin{array}{l}14.0 \pm \\
0.15^{\mathrm{a}}\end{array}$ & $\begin{array}{l}20.5 \pm \\
0.29^{\mathrm{a}}\end{array}$ \\
\hline Overall & & 5 & $\begin{array}{l}4.53 \pm \\
0.06^{\mathrm{A}}\end{array}$ & $\begin{array}{l}1801 \pm \\
0.71^{\mathrm{A}}\end{array}$ & $\begin{array}{l}4809 \pm \\
134^{\mathrm{B}}\end{array}$ & $\begin{array}{r}14.1 \pm \\
0.07^{\mathrm{A}}\end{array}$ & $\begin{array}{r}19.9 \pm \\
0.26^{\mathrm{A}}\end{array}$ \\
\hline
\end{tabular}

*: P-L-L: PRO-LYNE ${ }^{\circledR}$ level. Mean without a similar small superscript within a column and a group differ significantly $(\mathrm{P}<0.05)$. Overall mean without a similar capital superscript within a column differ significantly $(\mathrm{P}<0.05)$.

Improved growth of fish fed extruded floating diet may be due to the presence of pelleted floating diet above the water surface, which enables fish to benefit from it, as well as the fish movement and activity as a result of rise to water surface to feed, which works to improve digestion and absorption of feeds. But, the sinking diet on the feeder lose part of them as a result of movement of fish and a part of this pellets (as a waste that lowering the feed conversion and increases production costs, thus lowering the economic efficiency) download to the bottom of pond and mixed with mud, thus fish will not benefit from it, but even will change the water properties as a result of the accumulation of feed waste analyzed in water causing increased total ammonia concentration in ponds.

As in the present study also, Abou-Zied (2015) found that final mean weight and weight gain were higher of Nile tilapia in commercial farms fed extruded floating diet, while lower values were recorded with sinking diet. With regard to the effect of probiotic level on body weight and length, data in Table 6 showed that final weight was 177, 198, 188, 163, 183 and $185 \mathrm{~g} /$ fish for T1, T2, T3, T4, T5 and T6, respectively, while in Table 5 the mean length was 19.3, 21.3, 20.3, 19.2, 20.2, and $20.5 \mathrm{~cm}$. These results indicated that, the average body weight for level of probiotic $1 \% \mathrm{~T} 2$ was higher than other levels. The analysis of variance of these results indicated that, the differences among different levels were significant $(\mathrm{P}<0.05)$. These results are in agreement with those reported by Abdoulaye (2013) when studied the effects of dietary protein level and probiotic on growth performance, carcass composition and survival rate of fry mono-sex Nile tilapia. Significantly higher final weight of tilapia was found in T2 (198 g) than those of T1 (177 g), T1 $(163 \mathrm{~g})$ and T6 (185g), respectively (Table 6). Results presented in Tables 5 and 6 show that variations were significant $(\mathrm{P}<0.05)$ due to the interaction between food type (floating and sinking pellets) and probiotic $(0 \%, 1 \%$ and $2 \%)$, which indicated that these two factors act dependently on each other and also each of them had its own significant effect. 
Table 6: Mean \pm standard errors of growth performance parameters, and survival rate of the Nile tilapia fed floating and sinking diets supplemented with different levels of probiotic

\begin{tabular}{|c|c|c|c|c|c|c|c|}
\hline Diets type & P-L-L* \% & $\begin{array}{l}\text { Initial weight } \\
\text { (g/fish) }\end{array}$ & $\begin{array}{l}\text { Final weight } \\
\text { (g/fish) }\end{array}$ & $\begin{array}{l}\text { Weight gain } \\
\text { (g/fish) }\end{array}$ & $\begin{array}{l}\text { Average daily } \\
\text { gain (g/fish) }\end{array}$ & $\begin{array}{l}\text { SGR } \\
\text { (\%/day) }\end{array}$ & SR (\%) \\
\hline \multirow[t]{3}{*}{ Floating } & 0 & $\begin{array}{l}60.0 \pm \\
0.03^{\mathrm{a}}\end{array}$ & $\begin{array}{l}177 \pm \\
0.78^{c}\end{array}$ & $\begin{array}{l}117 \pm \\
0.78^{c}\end{array}$ & $\begin{array}{l}1.20 \pm \\
0.00^{\mathrm{b}}\end{array}$ & $\begin{array}{l}1.12 \pm \\
0.003^{\mathrm{b}}\end{array}$ & $\begin{array}{l}88.3 \pm \\
6.73^{\mathrm{a}}\end{array}$ \\
\hline & 1 & $\begin{array}{l}60.0 \pm \\
0.00^{\mathrm{a}}\end{array}$ & $\begin{array}{r}198 \pm \\
1.18^{\mathrm{a}}\end{array}$ & $\begin{array}{l}138 \pm \\
1.18^{\mathrm{a}}\end{array}$ & $\begin{array}{l}1.43 \pm \\
0.03^{\mathrm{a}}\end{array}$ & $\begin{array}{c}1.24 \pm \\
0.007^{\mathrm{a}}\end{array}$ & $\begin{array}{l}96.7 \pm \\
0.00^{\mathrm{a}}\end{array}$ \\
\hline & 2 & $\begin{array}{l}60.1 \pm \\
0.06^{\mathrm{a}}\end{array}$ & $\begin{array}{l}188 \pm \\
1.19^{b}\end{array}$ & $\begin{array}{l}128 \pm \\
1.21^{\mathrm{b}}\end{array}$ & $\begin{array}{l}1.33 \pm \\
0.03^{\mathrm{a}}\end{array}$ & $\begin{array}{l}1.19 \pm \\
0.006^{\mathrm{a}}\end{array}$ & $\begin{array}{l}96.7 \pm \\
0.00^{\mathrm{a}}\end{array}$ \\
\hline Overall & & $\begin{array}{l}60.0 \pm \\
0.02^{\mathrm{A}}\end{array}$ & $\begin{array}{l}188 \pm \\
3.10^{\mathrm{A}}\end{array}$ & $\begin{array}{l}128 \pm \\
3.11^{\mathrm{A}}\end{array}$ & $\begin{array}{l}1.32 \pm \\
0.04^{\mathrm{A}}\end{array}$ & $\begin{array}{l}1.19 \pm \\
0.018^{\mathrm{A}}\end{array}$ & $\begin{array}{l}93.9 \pm \\
2.39^{\mathrm{A}}\end{array}$ \\
\hline \multirow[t]{3}{*}{ Sinking } & 0 & $\begin{array}{l}60.0 \pm \\
0.00^{\mathrm{a}}\end{array}$ & $\begin{array}{l}163 \pm \\
6.41^{\mathrm{b}}\end{array}$ & $\begin{array}{l}103 \pm \\
6.41^{\mathrm{b}}\end{array}$ & $\begin{array}{l}1.07 \pm \\
0.09^{\mathrm{b}}\end{array}$ & $\begin{array}{l}1.03 \pm \\
0.043^{b}\end{array}$ & $\begin{array}{c}88.3 \pm \\
2.89^{\mathrm{a}}\end{array}$ \\
\hline & 1 & $\begin{array}{c}60.1 \pm \\
0.06^{\mathrm{a}}\end{array}$ & $\begin{array}{r}183 \pm \\
0.09^{\mathrm{a}}\end{array}$ & $\begin{array}{l}123 \pm \\
0.15^{\mathrm{a}}\end{array}$ & $\begin{array}{l}1.30 \pm \\
0.00^{\mathrm{a}}\end{array}$ & $\begin{array}{l}1.16 \pm \\
0.003^{\mathrm{a}}\end{array}$ & $\begin{array}{c}93.3 \pm \\
1.93^{\mathrm{a}}\end{array}$ \\
\hline & 2 & $\begin{array}{l}60.0 \pm \\
0.00^{\mathrm{a}}\end{array}$ & $\begin{array}{l}185 \pm \\
0.00^{\mathrm{a}}\end{array}$ & $\begin{array}{r}125 \pm \\
0.00^{\mathrm{a}}\end{array}$ & $\begin{array}{l}1.30 \pm \\
0.00^{\mathrm{a}}\end{array}$ & $\begin{array}{l}1.17 \pm \\
0.000^{\mathrm{a}}\end{array}$ & $\begin{array}{l}90.0 \pm \\
0.00^{\mathrm{a}}\end{array}$ \\
\hline Overall & & $\begin{array}{l}60.0 \pm \\
0.02^{\mathrm{A}}\end{array}$ & $\begin{array}{l}177 \pm \\
4.07^{\mathrm{B}}\end{array}$ & $\begin{array}{l}117 \pm \\
4.07^{\mathrm{B}}\end{array}$ & $\begin{array}{l}1.22 \pm \\
0.05^{\mathrm{B}}\end{array}$ & $\begin{array}{l}1.12 \pm \\
0.025^{\mathrm{B}}\end{array}$ & $\begin{array}{l}90.5 \pm \\
1.25^{\mathrm{A}}\end{array}$ \\
\hline
\end{tabular}

*: P-L-L: PRO-LYNE ${ }^{\circledR}$ level. Mean without a similar small superscript within a column and a group differ significantly $(\mathrm{P}<0.05)$. Overall mean without a similar capital superscript within a column differ significantly $(\mathrm{P}<0.05)$.

Average daily weight gain (ADWG): Table 6 shows mean of ADWG during the experimental period as effected by food type (floating and sinking pellets), where ADWGs for floating were $(\mathrm{P}<0.05)$ higher than for sinking pellets. In this regard, Abou-Zeid (2015) also reported that ADWGs were significantly $(\mathrm{P}<0.05)$ better with extruded floating diet, while lower values were recorded with sinking diet. The highest growth obtained in T2 might be due to probiotic with floating feed. Final weight of tilapia obtained in the present study is in agreement with the findings obtained by Ahmed et al. (2014). Daily weight gain of tilapia varied from $1.43 \pm$ 0.03 to $1.07 \pm 0.09 \mathrm{~g}$ (Table 6), which is in agreement with the findings of Ahmed et al. (2014) who obtained daily weight gain $1.45-1.98 \mathrm{~g}$ by applying commercial floated feed with probiotics in cages. Ahmed et al. (2013) has also found daily weight gain $1.56 \mathrm{~g}$ by applying prepared feed and $1.78 \mathrm{~g}$ by using commercial feed for tilapia reared for 70 days period. Results presented in Table 6 also showed that differences in DWG were significant $(\mathrm{P}<0.05)$ due to the interaction between food type (floating and sinking pellets) and probiotic levels $(0 \%, 1 \%$ and $2 \%$ ) which indicated that these two factors act dependently and also each of them had its own significant effect. As showed in this table, the best DWG was obtained for $2^{\text {rd }}$ treatment in the floating pellets at probiotic level $1 \%$.

Specific growth rate (SGR): Results in Table 6 showed that mean of SGR, during the experimental period as affected by pellets type and probiotic levels. As described in this table, the averages of SGR were $1.24 \pm 0.007$ to $1.03 \pm 0.043 \% /$ day for floating and sinking pellets, respectively. These results indicated that the SGR for floating pellets was higher $(\mathrm{P} \leq 0.05)$ than obtained in sinking one. Results presented in Table 6 showed that variation was significant due to the interaction between food type (floating and sinking pellets) and probiotic levels $(0 \%, 1 \%$, and $2 \%$ ), which indicated that these two factors act dependently on each other and also each of them had its own significant effect. As showed in Table 6, the highest $(\mathrm{P} \leq 0.05)$ SGR was obtained for $\mathrm{T} 2$ treatment (floating pellets 1.24) at probiotic level 1\%, while the lowest in the control group. The SGR values found in other two treatments were also significantly different. Values of SGR observed in the present study are lower than those reported by Diana et al. (1996), Ahmed et al. (2013) and Kunda et al. (2015). 
Survival rate: No significant difference was observed in the survival rate of Nile tilapia, it ranged from 88.30 to $96.70 \%$ (Table 6). In a previous study, survival rate of caged tilapia had been found to range from 95.76 to $97.54 \%$ (Ahmed et al., 2014) and 95.39 to $95.87 \%$ (Kunda et al., 2015).

Food and nutrients utilization: Food conversion ratio (FCR) of tilapia in this investigation was $20.05-2.63$ (Table 7), similar to the findings of Ahmed et al. (2013 and 2014) and Kunda et al. (2015) who reported that FCR values as 1.40 $1.51,1.11-1.41$ and 1.18 - 1.25, respectively for tilapia. Quality of delivered food and of rearing water are responsible for FCR. Protein efficiency ratio (PER) for tilapia in the present study varied from $1.89 \pm 0.02$ to $1.52 \pm 0.09$, which coincided with the finding obtained by Saha and Khatun (2014), who found that PER as 2.81 3.97 at stocking density of 5 fish per $\mathrm{m}^{3}$ for 105 days culture period by applying floating feed supplemented with probiotics.

Table 7: Feed and nutrients utilization parameters* of Nile tilapia fed floating and sinking diets supplemented with different levels of probiotic

\begin{tabular}{|c|c|c|c|c|c|c|c|}
\hline Diets type & P-L-L** \% & $\begin{array}{l}\text { Feed intake } \\
\text { g/ fish }\end{array}$ & $\begin{array}{l}\text { Feed } \\
\text { conversion ratio }\end{array}$ & Feed efficiency & $\begin{array}{l}\text { Protein efficiency } \\
\text { ratio }\end{array}$ & PPV \% & $\mathbf{K}$ \\
\hline \multirow[t]{3}{*}{ Floating } & 0 & $\begin{array}{l}259 \pm \\
12.7^{\mathrm{b}}\end{array}$ & $\begin{array}{l}2.21 \pm \\
0.12^{\mathrm{a}}\end{array}$ & $\begin{array}{c}0.45 \pm \\
0.02^{\mathrm{a}}\end{array}$ & $\begin{array}{l}1.80 \pm \\
0.10^{\mathrm{a}}\end{array}$ & $\begin{array}{l}35.2 \pm \\
2.34^{\mathrm{a}}\end{array}$ & $\begin{array}{l}0.80 \pm \\
0.10^{\mathrm{a}}\end{array}$ \\
\hline & 1 & $\begin{array}{r}284 \pm \\
2.17^{\mathrm{a}}\end{array}$ & $\begin{array}{l}2.06 \pm \\
0.02^{\mathrm{a}}\end{array}$ & $\begin{array}{l}0.49 \pm \\
0.01^{\mathrm{a}}\end{array}$ & $\begin{array}{l}1.89 \pm \\
0.02^{\mathrm{a}}\end{array}$ & $\begin{array}{c}33.3 \pm \\
1.28^{\mathrm{a}}\end{array}$ & $\begin{array}{l}0.40 \pm \\
0.06^{\mathrm{b}}\end{array}$ \\
\hline & 2 & $\begin{array}{l}286 \pm \\
6.99^{\mathrm{a}}\end{array}$ & $\begin{array}{l}2.22 \pm \\
0.05^{\mathrm{a}}\end{array}$ & $\begin{array}{c}0.45 \pm \\
0.01^{\mathrm{a}}\end{array}$ & $\begin{array}{l}1.74 \pm \\
0.04^{\mathrm{a}}\end{array}$ & $\begin{array}{c}28.7 \pm \\
1.30^{\mathrm{b}}\end{array}$ & $\begin{array}{c}0.53 \pm \\
0.03^{\mathrm{ab}}\end{array}$ \\
\hline Overall & & $\begin{array}{l}276 \pm \\
6.07^{\mathrm{A}}\end{array}$ & $\begin{array}{c}2.16 \pm \\
0.05^{\mathrm{B}}\end{array}$ & $\begin{array}{l}0.46 \pm \\
0.01^{\mathrm{A}}\end{array}$ & $\begin{array}{l}1.81 \pm \\
0.04^{\mathrm{A}}\end{array}$ & $\begin{array}{l}32.4 \pm \\
1.28^{\mathrm{A}}\end{array}$ & $\begin{array}{l}0.58 \pm \\
0.07^{\mathrm{A}}\end{array}$ \\
\hline \multirow[t]{3}{*}{ Sinking } & $\mathbf{0}$ & $\begin{array}{r}268 \pm \\
1.85^{\mathrm{a}}\end{array}$ & $\begin{array}{c}2.63 \pm \\
0.16^{\mathrm{a}}\end{array}$ & $\begin{array}{l}0.38 \pm \\
0.02^{b}\end{array}$ & $\begin{array}{l}1.52 \pm \\
0.09^{b}\end{array}$ & $\begin{array}{c}26.9 \pm \\
1.41^{\mathrm{b}}\end{array}$ & $\begin{array}{l}0.90 \pm \\
0.15^{\mathrm{a}}\end{array}$ \\
\hline & 1 & $\begin{array}{l}273 \pm \\
0.23^{\mathrm{a}}\end{array}$ & $\begin{array}{l}2.21 \pm \\
0.00^{\mathrm{b}}\end{array}$ & $\begin{array}{l}0.45 \pm \\
0.00^{\mathrm{a}}\end{array}$ & $\begin{array}{l}1.75 \pm \\
0.01^{\mathrm{a}}\end{array}$ & $\begin{array}{l}29.9 \pm \\
0.68^{\mathrm{ab}}\end{array}$ & $\begin{array}{l}0.57 \pm \\
0.09^{\mathrm{b}}\end{array}$ \\
\hline & 2 & $\begin{array}{l}273 \pm \\
0.87^{\mathrm{a}}\end{array}$ & $\begin{array}{c}2.18 \pm \\
0.01^{\mathrm{b}}\end{array}$ & $\begin{array}{l}0.46 \pm \\
0.00^{\mathrm{a}}\end{array}$ & $\begin{array}{l}1.76 \pm \\
0.01^{\mathrm{a}}\end{array}$ & $\begin{array}{l}33.2 \pm \\
1.15^{\mathrm{a}}\end{array}$ & $\begin{array}{l}0.50 \pm \\
0.12^{\mathrm{b}}\end{array}$ \\
\hline Overall & & $\begin{array}{c}271 \pm \\
0.98^{\mathrm{A}}\end{array}$ & $\begin{array}{l}2.34 \pm \\
0.09^{\mathrm{A}}\end{array}$ & $\begin{array}{l}0.43 \pm \\
0.01^{\mathrm{B}}\end{array}$ & $\begin{array}{l}1.68 \pm \\
0.05^{\mathrm{B}}\end{array}$ & $\begin{array}{l}30.0 \pm \\
1.06^{\mathrm{A}}\end{array}$ & $\begin{array}{l}0.66 \pm \\
0.09^{\mathrm{A}}\end{array}$ \\
\hline
\end{tabular}

*: Values are mean \pm standard errors. **: P-L-L: PRO-LYNE ${ }^{\circledR}$ level. Mean without a similar small superscript within a column and a group differ significantly $(\mathrm{P}<0.05)$. Overall mean without a similar capital superscript within a column differ significantly $(\mathrm{P}<0.05)$.

Condition factor (k): Table 7 shows mean of condition factor (k), at the start and at the end of the experiment affected by food types (floating and sinking pellets). As described in this table, the averages of initial (k) of O. niloticus were 0.58 and 0.66 , respectively. These results indicated that, the condition factor was decreased with extruded floating diet. It is advantageous to feed a floating food, because the farmers can directly observe the feeding intensity of their fish. Regarding to the effect of tested levels of probiotic on $(\mathrm{k})$, means of condition factor $(\mathrm{k})$, were $0.80,0.40$ and 0.53 for three levels of probiotic $0 \%, 1 \%$ and $2 \%$ floating diet, respectively (Table 7). While, at the end of the experiment, the mean of $\mathrm{k}$ were $0.90,0.57$ and 0.50 , for three levels of probiotic $0 \%, 1 \%$ and $2 \%$ sinking diet, respectively. The analysis of variance of these results indicated that, the differences among different levels were significant $(\mathrm{p}<0.05)$. These results are in agreement with those obtained by Abdoulaye (2013) who reported that $\mathrm{k}$ of fish was significantly improved with increasing dietary levels $0 \%, 1 \%$ and $2 \%$ of tested probiotic. Results presented in Table 7 due to the interaction effects between food type (floating and sinking pellets) and probiotic levels $(1 \%, 2 \%$ and $3 \%)$. 
Chemical composition: The changes in chemical composition during development and in response to studied factors are shown in Table 8. Proximate analysis showed significant $(\mathrm{P}<0.05)$ effects in the six treatments. Sinking diet released the highest values of fat and ash. This closely met with remarks of Abou-Zaid (2015) who emphasized that floating diet is commonly considered the most desirable for aquaculture, because it is usually consistent in quantity and quality. Data refers to fish carcass protein and lipid content that significantly $(\mathrm{P}<0.05)$ increased with increasing dietary protein levels and probiotic levels. Pedro et al. (2001), Tidwell et al. (2005), and Abdoulaye (2013) reported the increase in carcass protein content with the increase in dietary protein levels. In contrast, in the present study there was not any significant difference in body protein content of tilapia. While, there were significant differences between treatments in ether extract and crude fiber composition. This is in contrast with the findings obtained by Ahmed et al. (2012). Yet, carcass lipid content exhibited positive relation with dietary lipid levels in rainbow trout (Yamamoto et al., 2000 and Gumus and Ikiz, 2009). Laterally, other scientists reported similar results of different tilapia spp. (Davis and Stickney, 1978; Mazid et al., 1979; Winfree and Stickney, 1981 and Jauncey, 1982). Once the protein requirement of the fish was met; the excess protein was used for other bodily processes as indicated by the significantly higher crude fat content of the carcass of juveniles fed with sinking pellets. Dietary protein is the source of amino acids used for protein synthesis that represents normal growth (Shul'man, 1974). However, certain proportions of absorbed amino acid are used to obtain energy (Pfeffer, 1982) or stored as fat or glycogen (Shul'man, 1974 and Cowey and Sargent, 1979) and the amount depends mainly on the amino acid composition of dietary protein relative to fish needs, and the amount of energy provided by lipids and carbohydrates relative to that need to cover metabolic requirements (Pfeffer, 1982 and Wilson et al., 1985).

Table 8: Chemical composition* of Nile tilapia fed floating and sinking diets supplemented with different levels of probiotic

\begin{tabular}{|c|c|c|c|c|c|c|c|}
\hline \multirow[t]{2}{*}{ Diets type } & \multirow[t]{2}{*}{ P-L-L** \% } & \multicolumn{6}{|c|}{ \% On Dry matter basis } \\
\hline & & DM & $\mathbf{C P}$ & $\mathbf{E E}$ & CF & Ash & CHO \\
\hline \multicolumn{2}{|c|}{$\begin{array}{l}\text { Initial analysis } \\
\text { Final analysis }\end{array}$} & $25.55 \pm 2.68$ & $56.97 \pm 4.05$ & $11.87 \pm 1.13$ & $2.88 \pm 0.05$ & $19.87 \pm 0.38$ & $8.42 \pm 0.097$ \\
\hline \multirow[t]{3}{*}{ Floating } & $\mathbf{0}$ & $32.00 \pm 0.00 \mathrm{a}$ & $55.65 \pm 1.11 \mathrm{a}$ & $22.53 \pm 1.08 \mathrm{a}$ & $3.08 \pm 0.02 b$ & $14.25 \pm 0.69 b$ & $4.40 \pm 0.23 \mathrm{a}$ \\
\hline & 1 & $29.06 \pm 0.00 \mathrm{c}$ & $57.30 \pm 1.73 \mathrm{a}$ & $20.46 \pm 0.53 a$ & $0.67 \pm 0.07 \mathrm{c}$ & $17.42 \pm 0.78 \mathrm{a}$ & $4.60 \pm 0.23 \mathrm{a}$ \\
\hline & 2 & $29.17 \pm 0.00 b$ & $54.59 \pm 2.33 \mathrm{a}$ & $20.25 \pm 0.23 a$ & $4.26 \pm 0.15 \mathrm{a}$ & $17.00 \pm 0.58 \mathrm{a}$ & $3.84 \pm 0.20 \mathrm{a}$ \\
\hline Overall & & $30.08 \pm 0.48 \mathrm{~A}$ & $55.85 \pm 0.98 \mathrm{~B}$ & $21.08 \pm 0.51 \mathrm{~A}$ & $2.67 \pm 0.53 \mathrm{~A}$ & $16.23 \pm 0.60 \mathrm{~A}$ & $4.28 \pm 0.16 \mathrm{~A}$ \\
\hline \multirow[t]{3}{*}{ Sinking } & $\mathbf{0}$ & $26.06 \pm 0.00 \mathrm{~b}$ & $63.64 \pm 0.39 \mathrm{a}$ & $15.34 \pm 0.91 b$ & $1.56 \pm 0.20 \mathrm{a}$ & $16.15 \pm 1.21 \mathrm{ab}$ & $3.24 \pm 0.09 b$ \\
\hline & 1 & $24.64 \pm 0.00 \mathrm{c}$ & $65.96 \pm 1.08 \mathrm{a}$ & $10.43 \pm 0.58 \mathrm{c}$ & $1.00 \pm 0.06 \mathrm{~b}$ & $19.65 \pm 1.04 \mathrm{a}$ & $3.36 \pm 0.24 b$ \\
\hline & 2 & $30.30 \pm 0.00 \mathrm{a}$ & $57.54 \pm 1.40 \mathrm{~b}$ & $22.05 \pm 1.16 \mathrm{a}$ & $1.50 \pm 0.17 \mathrm{ab}$ & $13.85 \pm 0.87 b$ & $4.51 \pm 0.29 a$ \\
\hline Overall & & $27.00 \pm 0.85 \mathrm{~B}$ & $62.38 \pm 1.36 \mathrm{~A}$ & $15.94 \pm 1.74 \mathrm{~B}$ & $1.35 \pm 0.12 \mathrm{~B}$ & $16.55 \pm 0.99 \mathrm{~A}$ & $3.70 \pm 0.23 \mathrm{~B}$ \\
\hline
\end{tabular}

*: Values are means \pm standard errors. **: P-L-L: PRO-LYNE ${ }^{\circledR}$ level. Means without a similar small superscript within a column and a group differ significantly $(\mathrm{P}<0.05)$. Overall means without a similar capital superscript within a column differ significantly $(\mathrm{P}<0.05)$.

Economic study: The economic efficiency parameters of the tested diets are presented in Table 9. The calculations depended on the average price of dietary ingredients of year 2017; where local marked prices of their ingredients were as fish meal 16400 LE, soybean meal 7350 LE, Yellow corn 3800 LE, oil 31550 LE, Vit. \&Min. 25000 LE and black seed meal 1450 LE. The calculated figures showed the high cost of one ton of all diets included the probiotic. However, the control diet recorded the lowest price. The diets containing $1 \%$ and $2 \%$ floating diet showed the hifgest fish gain compared with the other diets. Therefore, $1 \%$ floating diet showed the lowest feed cost / kg gain. However, diet No. 2 and 6 (including 1\% PRO- 
LYNE $^{\circledR}$-floating and $2 \%$ PRO-LYNE-sinking diets) reflected the best fish body gains. Thus, these low levels (1\% and 2\% PRO-LYNE ${ }^{\circledR}$ ) gave the best feed cost / kg gain being (16.71 and 17.34 LE).

Table 9: Data of the economic efficiency parameters of Nile tilapia fed floating and sinking diets supplemented with different levels of probiotic

\begin{tabular}{lcccccc}
\hline $\begin{array}{l}\text { Diets } \\
\text { type }\end{array}$ & $\begin{array}{c}\text { P-L-L** } \\
\text { \% }\end{array}$ & $\begin{array}{c}\text { Feed intake } \\
\text { (g/fish) }\end{array}$ & $\begin{array}{c}\text { Cost of one- } \\
\text { ton diet (LE) }\end{array}$ & $\begin{array}{c}\text { Decrease } \\
\text { feed cost } \\
\text { (LE) }\end{array}$ & $\begin{array}{c}\text { Total fish } \\
\text { gain }\end{array}$ & $\begin{array}{c}\text { Feed Cost / kg } \\
\text { gain (LE) }\end{array}$ \\
\hline \multirow{3}{*}{ Floating }
\end{tabular}

Feed cost $/ \mathrm{kg}(\mathrm{LE})=$ feed intake $*$ cost of ton feed $* 1000 /$ total gain. **: P-L-L: PRO-LYNE ${ }^{\circledR}$ level.

\section{CONCLUSION}

In conclusion, the present study revealed that performance and production of Nile tilapia reared in net hapas in earthen ponds significantly increased, when fed the floating pellets supplemented with PRO-LYNE ${ }^{\circledR}$ probiotic at level 1\% (T2). This is confirmed in Table 9 regarding the economic assessment, where the best economic efficiency return was observed for $\mathrm{T} 2$.

\section{REFERENCES}

A.O.A.C. (1990). Official Method of Analysis, $15^{\text {th }}$ Ed. Association of Official Analysis of Chemists, Washington D.C.

Abd El-Maksuod, A.M.; Allam, S.M., Abou-Fotoh, G.E. and Abou Zied, R.M. (1998). Evaluation of Nigella seeds as a feed additive in diets of Nile tilapia. Fayoum. J. Agric. Res. \& Dev., 12:170-181.

Abdel-Hakim, N.F.; Bakeer, M.N. and Soltan, M.A. (2002). Water Environment for Fish Culture. Deposition No. 4774.

Abdelhamid, A.F.B. (2019a). Water Quality Properties in Fish Farms. 99P, Al-Azhar Univ. (under publication).

Abdelhamid, A.M. (1996). Field and Laboratorial Analysis in Animal Production. Dar Al-Nashr for the Egyptian Universities. Cairo, 680p, 977-5526-47-7, Deposition No. 11318/1996.

Abdelhamid, A.M. (2019b). The Modern Methods of Aquaculture. Deposit No. 25438/2018, $718 \mathrm{P}$.

Abdelhamid, A.M.; khalil, F.F., El Barbary, M.I., Zaki, V.H. and Hussein, H.S. (2002). Feeding Nile tilapia on Biogen to detoxify aflatoxin diets. Proc. Con. Animal, Fish Prod. Mansoura, 24- 25 Sep., pp: 207-230.

Abdoulaye, L. (2013). Effect of dietary protein level on growth performance carcass composition and survival rate of fry mono-sex Nile tilapia O. niloticus reared under re- circulating system. Journal of Biology and Life Science, 4 (2).

Abou-Zied, R.M. (2015). Effect of diet extruded type on growth performance feed utilization and economic efficiency of Nile tilapia in commercial farms. Egyptian J Nutrition and Feeds 18 (1):143-150.

Ahmed, G.U.; Sultana, N.; Shamsuddin, M. and Hossain, M.B. (2013). Growth and production performance of mono-sex tilapia (Oreochromis niloticus) fed with 
homemade feed in earthen mini ponds. Pakistan J. Biol. Sci., 16 (23):17811785 .

Ahmed, T.; Hasan, S.J.; Hossain, M.R.; Haidar, I.; Rubel, A.K.M.S.A. and Pramanik, M.H. (2014). Assessment on impact of dietary probiotic supplementation on growth indices of mono-sex tilapia (Oreochromis niloticus) cage culture at Dakatia River, Chandpur, Bangladesh. World Journal of Fish and Marine Sciences, 6 (5): 441-446.

Ahmed, M.; Qureshi, T.; Singh, A.B.; Susan, N.; Kamlesh, B. and Salman, R.C. (2012). Effect of dietary protein, contest growth, feed efficiency and carcass composition of Cyprinus carpio communes fingerlings. International Journal of Fisheries and Aquaculture, 4 (3): 30-40.

Aly, S.M.; Mohamed, M.F. and John, G. (2008). Effect of probiotics on the survival, growth and challenge infection in Tilapia nilotica (Oreochromis niloticus). Aquaculture Research, 39: 647-656.

APHA (2005). Standard Methods for the Examination of Water \& Wastewater. American Public Health Association.

Boyd, C.E. (1982). Water Quality Management for Pond Fish Culture. Elsevier Scientific Publishing Co. Amsterdam: 318.

Burr, G.; Hume, M., Neill, W.H. and Gatlin III, D.M. (2008). Effects of probiotics on nutrient digestibility of soybean-meal-based diets by red drum (Sciaenops ocellatus). Aquaculture Research, 39: 1680-1686.

Cowey, C.B. and Sargent, J.R. (1979). Nutrition. In: Fish Physiology. (eds. W.S. Hoar, D.J. Randall and J.R. Brett), pp. 1-69. Academic Press, London.

Cruz, P.M.; Ibanez, A.L.; Hermosillo, O.A.M. and Ramırez Saad, H.C. (2012). Use of probiotics in aquaculture. International Scholarly Research Network (ISRN), Microbiology, Volume 2012. pp. 13.

Davis, A.T. and Stickney, R.R. (1978). Growth responses of Tilapia aurea to dietary protein quality and quantity. Transaction of the American Fisheries Society, 107: 479-483.

Defoirdt, T.; Sorgeloos, P. and Bossier, P. (2011). Alternatives to antibiotics for the control of bacterial disease in aquaculture. Current Opinion in Microbiology, 14: 251-258.

Diana, J.S.; Lin, C.K. and Yi, Y. (1996). Timing of supplemental feeding for tilapia production. J. World Aquacult. Soc., 27: 410-419.

Duncan, D. (1955). Multiple range and multiple F-tests. Biometrics, 11: 1-42.

El-Rhman, A.M.A.; Khattab, Y.A. and Shalaby, A.M. (2009). Micrococcus luteus and Pseudomonas species as probiotics for promoting the growth performance and health of Nile tilapia, Oreochromis niloticus. Fish Shellfish Immunology, 27: $175-180$.

FAO (Food and Agriculture Organization) (2004). Fishstat Plus. Aquaculture Production 1950- 2002. Food and Agriculture Organization FAO, Rome, Italy.

FAO (Food and Agriculture Organization) (2012). Fishstat Plus, Vers. 2.32. Rome, Italy. Ferguson, R.M.W.; Merrifield, D.L., Harper, G.M., Rawling, M.D. and Mustafa, S. (2010). The effect of Pediococcus acidilactici on the gut microbiota and immune status of on-growing red tilapia (Oreochromis niloticus). Journal of Applied Microbiology, 109: 851-862.

Fitzsimmons, K. (2004). Development of new products and markets for the global tilapia trade. In: Proceeding of the $6^{\text {th }}$ International Symposium on Tilapia in Aquaculture, Manila, Philippines (ed. By R. Bolivar, G. Mair \& K Fitzsimmons), pp: 624-633. 
Grisdale-Helland, B.; Helland, S.J. and Gatlin, D.M. (2008). The effects of dietary supplementation with mannanoligosaccharide, fructooligosaccharide or galactooligosaccharide on the growth and feed utilization of Atlantic salmon (Salmo salar). Aquaculture, 283: 163-167.

Gumus, E. and Ikiz, R. (2009). Effect of dietary levels of lipid and carbohydrate on performance, chemical contents and digestibility in rainbow trout, Oncorhynchus mykiss. Pakistan Veterinary Journal, 29 (2): 59-63.

Hassan, R. (1992). Acute ammonia toxicity of red tilapia and sea bass. Fisheries Bulletin of the Department of Fisheries, Malaysia No. 73. 8 pp.

Honsheng, M. (2010). Effects of probiotics on activities of digestive enzyme for tilapia. Journal of South China Normal University, 2: 10-15.

Irianto, A. and Austin, B. (2002). Use of probiotics to control furunculosis in rainbow trout, Oncorhynchus mykiss (Walbaum). Journal of Fish Diseases, 25: 333-342.

Jauncey, K. (1982). The effects of varying dietary protein on the growth, food conversion, protein utilization and body composition of juvenile tilapias (Sarotherodon mossambicus). Aquaculture, 27: 43-54.

Jobling, S. (1983). A total protein and acid needs. In: I.J.E. Halve, Nutrition. Academic Press: New York, pp. 106-143.

Kannadhason, S.; Muthukumarappan, K. and Rosentrater, K.A. (2009). Effects of ingredients and extrusion parameters on aquafeeds containing DDGS and tapioca starch. J. Aquacult. Feed Sci. Nutr., 1 (1): 6-21.

Kunda, M.; Dev, A.R. and Islam, M.J. (2015). Comparison of production performance and economics between mono-sex and mixed-sex tilapia (Oreochromis niloticus). SAU Res. Prog. Rep. No. 02, Sylhet Agricultural University, Sylhet, Bangladesh, 31-37 pp.

Lim, C.E.; Webster, C.D. and Li, M.H. (2006). Feeding Practices. In: C.E. Lim \& C.D. Webster, eds. Tilapia Biology, Culture and Nutrition, pp. 547-559. New York, Haworth Press Inc., 678 pp.

Limbu, S.M. and Jumanne, K. (2014). Effect of restricted and re-feeding regime on feeding cost, growth performance, feed utilization and survival rate of mixed sex Nile tilapia Oreochromis niloticus cultured in tanks. Int. J. Fish Aquat. Stud., 2 (1): 118-123.

Marzouk, M.S.; Moustafa, M.M. and Mohamed, N.M. (2008). The influence of some probiotics on the growth performance and intestinal microbial flora of Oreochromis niloticus. Proceedings of $8^{\text {th }}$ International Symposium on Tilapia in Aquaculture, Cairo, Egypt. pp. 1059-1071.

Mazid, M.A.; Tanaka, Y.; Katayama, T.; Rahman, M.A.; Simpson, K.L. and Chichester, C.O. (1979). Growth response to Tilapia zillii fingerlings fed isocaloric diets with variable protein levels. Aquaculture, 18: 115-122.

Merrifield, D.L.; Dimitroglou, A.; Foey, A.; Davies, S.J. and Baker, R.T.M. (2010). The current status and future focus of probiotic and probiotic applications for salmonids. Aquaculture, 302: 1-18.

Mussatto, S.I. and Mancilha, I.M. (2007). Non-digestible oligosaccharides: A review, Carbohydrate Polymers, 68: 587-597.

NRC (1993). Nutrient Requirement of Fish. National Academy Press. Washington, Dc, P.114.

Nwanna, L.C. (2002). Performance of hybrid Clariid catfish fingerlings (Clarias gariepinus $\hat{\sigma} \times$ Heterobranchus bidorsalis \&) fed poultry layer waste diets in aquaria. J. Appl. Aquacult., 12 (3): 99-106. 
Otte, G. and Rosenthal, H. (1979). Management of a closed brackish water system for high density fish culture by biological and chemical water treatment. Aquaculture, 18: 169-181.

Pedro, N.D.; Guijarro, A.L.; Delgado, M.J.; Patina, L.P.; Pinillos, M.L. and Bedate, M.A. (2001). Influence of dietary composition on growth and energy reserves in Tench, Tincta tincta. Journal of Applied Ichthyology, 17: 25-29.

Pfeffer, E. (1982). Utilization of dietary protein by salmonids. Comparative Biochemistry and Physiology (B), 73: 51-57.

Rahman, M.S. (1992). Water quality management in aquaculture. BRAC Prokashana, 66, Mohakhali, Dhaka-1212, Bangladesh: 84.

Saha, S.B. and Khatun, M.S. (2014). Production performance of mono-sex Nile tilapia, Oreochromis niloticus (Linnaeus, 1758) in brackish water ponds. Bangladesh J. Zool., 42 (2): 261-269.

Santiago, C. B. and Lovell, R.T. (1988). Amino acid requirements for growth of Nile tilapia. The Journal of Nutrition, 118 (12): 1540-1546.

SAS (2006). SAS statistical guide for personal computer, SAS Institute Inc. Cary, NC.

Shelby, R.A.; Lim, C.E.; Aksoy, M. and Klesius, P.H. (2006). Effect of probiotic diet supplements on disease resistance and immune response of young Nile tilapia, Oreochromis niloticus. Journal of Applied Aquaculture, 18: 23-34.

Shul'man, G.E. (1974). Life cycles of fish. Physiology and Biochemistry. Keter Publishing House, Jerusalem, 258 pp.

Sinha, A.K; Kumar, V.; Makkar, H.P.; De Boeck, G. and Becker, K. (2011). Nonstarch polysaccharides and their role in fish nutrition-A review. Food Chem., 127 (4): 1409-1426.

Sorensen, M. (2012). A review of the effects of ingredient composition and processing conditions on the physical qualities of extruded high-energy fish feed as measured by prevailing methods. Aquacult. Nutr., 18 (3): 233-248.

Tidwell, J.H.; Coyle, S.D.; Bright, L.A. and Asharian, Y. (2005). Evolution of plant and animals source proteins for replication of fish meal in practical diets for the largemouth bass, Microbteus salmoides. Journal World Aquaculture Society, 36: 454-463.

Verschuere, L.; Rombaut, G.; Sorgeloos, P. and Verstraete, W. (2000). Probiotic bacteria as biological control agents in aquaculture. Microbiology and Molecular Biology Review, 64: 655-671.

Wang, Y.C.; Chang, P.S. and Chen, H.Y. (2008). Differential time series expression of immune related genes of Pacific white shrimp in response to dietary inclusion of $\beta$-1, 3-glucan. Shellfish Immunology, 24: 113-121.

Wee, K.L. and Shu, S.W. (1989). The nutritive value of boiled feed -fat Soy bean in pelted feed for Nile tilapia. Aquaculture, 81:303-314.

Wilson, R.P.; Gatlin III, D.M. and Poe, W.E. (1985). Postprandial changes in serum amino acids of channel catfish diets containing different levels of protein and energy. Aquaculture, 49: 101-110.

Winfree, R.A. and Stickney, R.R. (1981). Effects of dietary protein and energy on growth, feed conversion efficiency and body composition of Tilapia aurea. Journal of Nutrition, 111: 1001-1012.

Yamamoto, T.; Unuma, T. and Akiyama, T. (2000). The influence of dietary protein and fat levels on tissue free amino acid levels of fingerling rainbow trout (Oncorhynchus mykiss). Journal of Aquaculture, 182 (3-4): 353-372. 
Yousefian, M. and Amiri, M.S. (2009). A review of the use of probiotic in aquaculture for fish and shrimp. African Journal of Biotechnology, 8: 73137318.

Zhou, Z.G.; Ding, Z.K. and Huiyuan, L.V. (2007). Effects of dietary short-chain fructooligosaccharides on intestinal microflora, survival, and growth performance of juvenile white shrimp, Litopenaeus vannamei. Journal of the World Aquaculture Society, 38: 296-301.

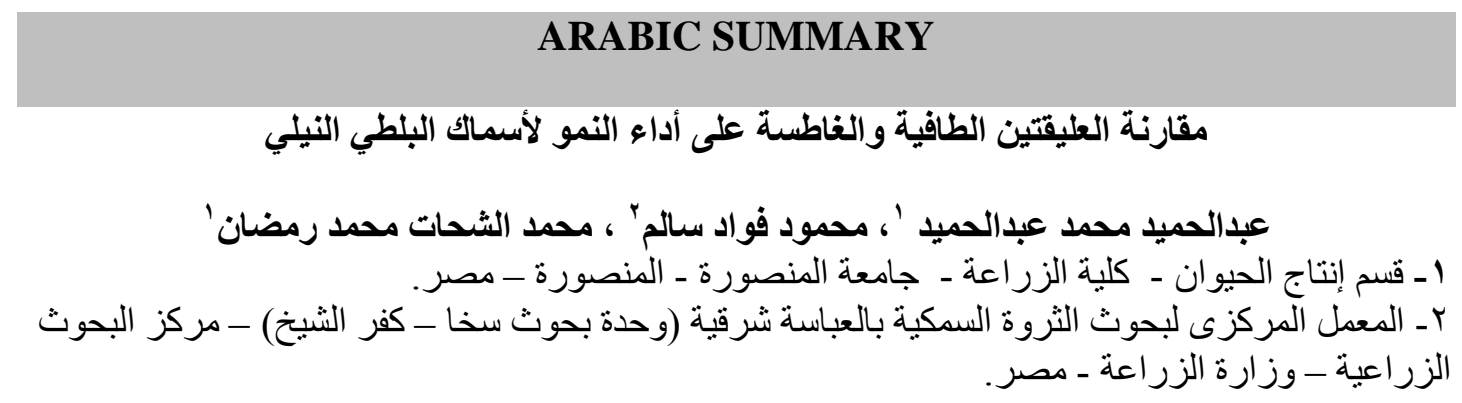

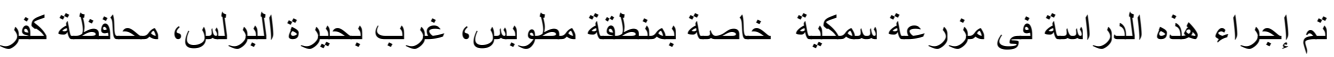

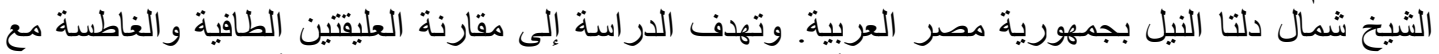

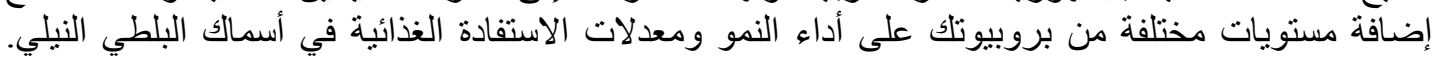

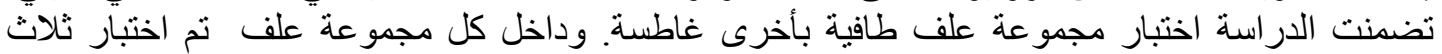

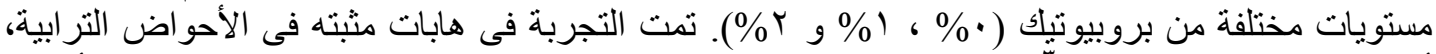

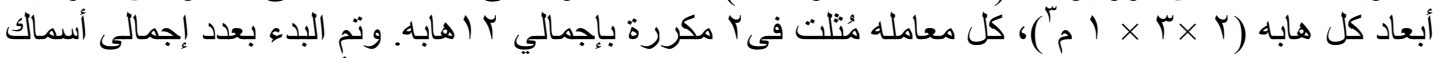

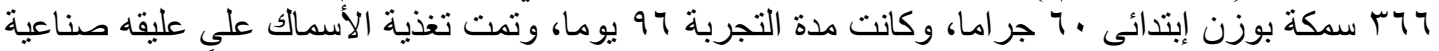

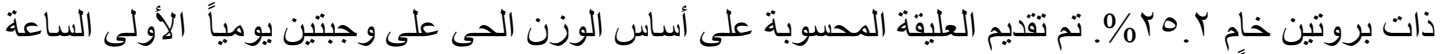

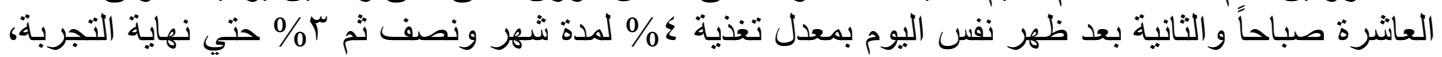

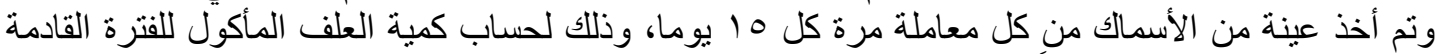

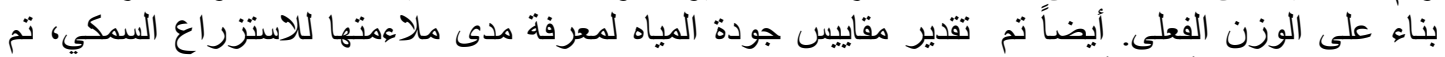

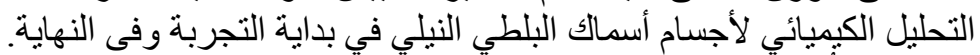

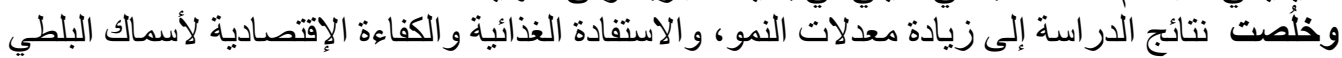

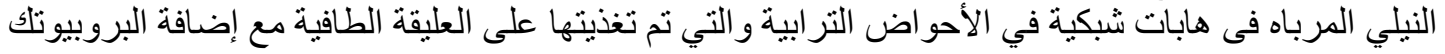

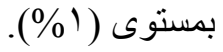

